\title{
Use of physiotherapy resources for patients with fibromyalgia
}

\section{A utilização de recursos fisioterapêuticos para portadores de fibromialgia}

\author{
Antonio José Sarmento da Nóbrega', Maria de Fátima Alcântara Barros², Antonio Geraldo Cidrão de Carvalho², \\ Maria das Graças Rodrigues Araújo ${ }^{3}$, Neide Maria Gomes de Lucena ${ }^{4}$
}

\begin{abstract}
Introduction: Fibromyalgia is a non-inflammatory rheumatic syndrome of unknown etiology manifested in the musculoskeletal system through diffuse and chronic pain and presence of tender points, which may be associated with fatigue, anxiety, muscle stiffness, skin sensitivity, pain after exercise, functional impairment and sleep disorders. Objective: This study aimed to perform a systematic literature review in order to check which physiotherapy resources are mostly used today and what are the most significant results in the treatment of fibromyalgia. Method: An integrative literature review was conducted by searching electronic databases of indexed data such as Latin American and Caribbean Health Sciences (LILACS), MEDLINE/ PubMed and Scientific Electronic Library Online (SCIELO). Randomized clinical trials were selected in the period from January 2001 to June 2013 published in Portuguese, English and Spanish. Methodological quality was assessed using the Jadad Quality Scale. Results: Overall, 522 studies were reviewed in full and only 13 were included after application of the exclusion criteria. Among these, articles that addressed the use of electrotherapic resources $(n=4)$, hydrotherapy $(n=3)$, conventional therapy $(n=3)$, physical exercise $(n=2)$ and multidisciplinary treatment $(n=1)$ were identified, with diversified results, protocols and application times of each methodology. Conclusion: It has been found that there are a small number of studies with scientific relevance published in the last 10 years evidencing techniques that have obtained better results in the treatment of patients with fibromyalgia. Further studies with better design aimed at obtaining more conclusive results should be conducted.
\end{abstract}

Keywords: Fibromyalgia; Physiotherapy; Physiotherapy resources.

\section{RESUMO}

Introdução: A fibromialgia é uma síndrome reumática não inflamatória, de etiologia desconhecida, que se manifesta no sistema musculoesquelético, por meio de dor difusa e crônica, presença de pontos sensíveis (tender points), podendo estar associada com a fadiga, a ansiedade, a rigidez muscular, a sensibilidade cutânea, a dor após o exercício físico, a incapacidade funcional e a anormalidades do sono. Objetivo: $O$ estudo teve como objetivo realizar uma revisão sistemática da literatura, no intuito de verificar quais os recursos fisioterapêuticos mais utilizados na atualidade, como também quais os resultados mais significativos no tratamento da fibromialgia. Método: Foi realizado um estudo de revisão integrativa da literatura, por meio de busca nas bases eletrônicas de dados informatizadas e indexadas, como Literatura Latino-Americana e do Caribe em Ciências da Saúde (LILACS), MEDLINE/Pubmed e Scientific Eletronic Library Online (SCIELO). Foram selecionados ensaios clínicos randomizados, entre os períodos de janeiro de 2001 a junho de 2013 , em língua portuguesa, inglesa e espanhola. A qualidade metodológica foi verificada através da Escala de Qualidade de Jadad. Resultados: 522 estudos foram revisados na integra, sendo que somente 13 foram incluídos após aplicação dos critérios de exclusão. Dentre estes, foram identificados artigos que abordaram a utilização de recursos eletroterápicos $(n=4)$, hidroterapia $(n=3)$, fisioterapia convencional $(n=3)$, exercícios físicos $(n=2)$ e tratamento multidisciplinar $(n=1)$, sendo diversificados os resultados, protocolos e tempos de aplicação referentes a cada modalidade. Conclusão: Foi constatada a existência de um número pequeno de estudos, com relevância científica, publicados nos últimos 10 anos, evidenciando as técnicas que obtiveram melhores resultados no tratamento dos portadores de fibromialgia. Torna-se necessário a elaboração de estudos com um melhor delineamento, ensejando resultados mais conclusivos.

Palavras-chave: Fibromialgia; Fisioterapia; Recursos fisioterapêuticos.

\footnotetext{
Corresponding author: Antonio Geraldo Cidrão de Carvalho. Campus Universitário I, s/n, Cidade Universitária, Zip Code: 58051-900, João Pessoa (PB), Brazil. E-mail: gecidrao@yahoo.com.br

${ }^{2}$ Physical Therapy Department of Universidade Federal da Paraíba (UFPB); researchers from the Fisioterapia em Saude Coletiva laboratory (LabFISC) of the Nucleo de Estudos e Pesquisas Epidemiológicas em Fisioterapia e Saúde (NEPEFIS), Joao Pessoa (PB), Brazil.

Full list of author information is available at the end of the article.

Financial support: The study receives funding of Conselho Nacional de Desenvolvimento Científico e Tecnológico (CNPq)/Pró-Reitoria de Pós-Graduação e Pesquisa/UFPB, through Edital do Programa Institucional de Bolsas de Iniciação Científica (PIBIC).
}

Submission date 06 September 2015; Acceptance date 02 December 2015; Online publication date 18 December 2015 


\section{INTRODUCTION}

Fibromyalgia is a non-inflammatory rheumatic syndrome of unknown etiology, manifested in the musculoskeletal system through diffuse and chronic pain, presence of tender points and may be associated with fatigue, anxiety, muscle stiffness, skin sensitivity, pain after exercise, functional impairment and sleep abnormalities. ${ }^{(1)}$

The global average prevalence is $2.7 \%$, ranging from $0.4 \%$ in Greece to $9.3 \%$ in Tunisia. In continental terms, the average is $3.1 \%$ in the Americas, $2.5 \%$ in Europe and $1.7 \%$ in Asia. Regarding gender, the average is $4.2 \%$ (female) and $1.4 \%$ (male). ${ }^{(2)}$ In Brazil, a study was conducted on the prevalence of rheumatic diseases in which fibromyalgia, occurred in $2.5 \%$ the population of Montes Claros in Minas Gerais. ${ }^{(3)}$ Another study conducted with elderly found the prevalence of $5.5 \%$, the most common symptom pain in women than men. ${ }^{(4)}$

Initially, the criteria for the diagnosis of fibromyalgia have been defined by the American College of Rheumathology (ACR) in 1990. From 2010 new diagnostic criteria were introduced, using a self-administered questionnaire is recommended, more suitable for epidemiological studies population-based, on basic health care. ${ }^{(5-7)}$

Ozgocmen et al. ${ }^{(8)}$ reported that there is a trend of increasing prevalence of fibromyalgia in fibromyalgia patients relatives, relating found the genetic and environmental factors. The region of chromosome 17p11.2-q11.2 showed suggestive evidence of connection with fibromyalgia, particularly in the serotonin transporter gene (SLC6A4) and transient receptor potential vanilloid 2 (TRPV2). ${ }^{(9)}$

Some neurotransmitters such as serotonin, norepinephrine, dopamine, substance $\mathrm{P}$, and endorphins, enkephalins target proved to be during the course of the hyperactive syndrome. As regards tender points, some viruses, such as coxsackie $B$ and parvovirus seem to be involved. ${ }^{(10)}$ Some cytokines express receptors for bacteria and viruses, may also be some connection between them. ${ }^{(11)}$

The symptoms of fibromyalgia often cause great impact on the daily lives of its carriers, providing a break from the routine, the consequence of which tends to maintain over time, due to the chronic nature of the disease. (12) In all patients the diffuse and chronic pain is the presenting symptom involving the peripheral and axial skeleton. The character of the pain is variable and can be burning, stabbing, weight, "fatigue type" or a bruise. The main symptoms that affect fibromyalgia patients are sleep disturbance, fatigue and stiffness in the body. Other symptoms such as skin sensitivity, irritable bowel syndrome, irritable bladder syndrome, cognitive disorders, migraine, dizziness, fluid retention, paresthesia, Raynaud's phenomenon, temporomandibular dysfunction, mood swings, anxiety and depression are also commonly found. ${ }^{(13-14)}$ High levels of pain in patients with fibromyalgia can interfere with the development of professional and social activities, motor and cognitive tasks as well as the destabilization of family relationships. ${ }^{(4)}$ Depression is often linked to reduced quality of life. ${ }^{(12)}$

Frequently, the therapeutic approach used in the treatment of fibromyalgia is directed only to the alleviation of symptoms. Physical therapy plays an important role in addressing this grievance through several of its therapeutic features such as electrotherapy, hydrotherapy and kinesiotherapy, among others, ${ }^{(15)}$ contributing to the reduction of pain, to improve flexibility and strength muscle, restoring restorative sleep, improve self-esteem, sense of well-being and consequently improving the quality of life of patients with fibromyalgia. ${ }^{(16-17)}$

The hydrotherapy has been used more frequently in the treatment of fibromyalgia to promote different reactions from those experienced on the ground. Thus, aquatic exercises are well tolerated because the water thermal environment helps to reduce pain and muscle spasms, ${ }^{(18)}$ increasing total sleep time (VITORINO, et al., 2006), improving peripheral circulation, benefiting venous return, as well as providing a massager and relaxing effect. ${ }^{(19)}$

The transcutaneous electrical nerve stimulation (TENS) has produced important results in the fight against pain. ${ }^{(20)}$ TENS is a method to produce pain relief by applying a biphasic rectangular wave pulse through electrodes on the skin surface. Depending on the modulation frequency, the working principle of TENS is associated with the gate control theory of pain or the release of endogenous opioids. ${ }^{(21)}$ The low frequency TENS increases $\beta$-endorphin and serotonin levels in the nervous system central. ${ }^{(22)}$

Therapeutic exercise is widely used in improving the quality of life being effective in reducing the symptoms of individuals with fibromyalgia. ${ }^{(23)}$ Aerobic exercise of low intensity and stretching on the ground improves pain, functional capacity, physical and social aspects and mental health. ${ }^{(24)}$

Based on these assumptions, the study aims to systematically review the literature in order to check which physical therapy resources most used today, but also what are the most significant results in the treatment of fibromyalgia.

\section{METHODS}

We performed an integrative review of literature through electronic databases of computerized and indexed data, searching for scientific articles in databases of health sciences in general and Latin American and Caribbean Health Sciences (LILACS), MEDLINE/PubMed and Scientific Electronic Library Online (SciELO) using the following key words and their combinations: fibromylagia, physiotherapy, eletrotherapy, hidrotherapy, exercise and kinesiotherapy.

Scripts were used for structured design of the research. The articles identified were considered for analysis when it came to original studies available in its entirety through access to the Journals Portal of Periódicos da Coordenação de Aperfeiçoamento Pessoal de Nível Superior (CAPES), keeping the terminology of the authors, published in Portuguese, 
English or Spain, from January 2001 to June 2013, which made reference in its content resources and physical therapy techniques related to fibromyalgia patients.

It was adopted as exclusion criteria review articles, experimental animal studies, case reports and editorials, completion of course work are, items only relating to quality of life, dissertations and theses, ie documents they were not in article format, items not explored the theme of the study or not detailed protocols and score on the Jadad Quality Scale less than 3.

To verify the quality of the studies was applied to Jadad Quality scale, ${ }^{(25)}$ whose scores (randomness, random, double blind, masking, description of losses and exclusions) of less than 3 were not considered methodological quality. Were presented the results of this review, the studies that characterized the randomized clinical trials.

\section{RESULTS}

Table 1 shows the results of the descriptors used in the research, were identified 522 articles, distributed in the LILACS database - 22 articles in SCIELO base - 04 articles and Medline/PubMed - 496 articles. The search strategy with fibromyalgia descriptors and physiotherapy was the one with the greatest number of articles in three databases (420 publications).

The study excluded 509 articles that not fit the inclusion criteria of the study. Of these, the full text was not available in 183 papers, review articles totaled 118 publications, 93 studies did not show adequate methodological quality, according to JADAD scale, not explored the theme of the study or not detailed its protocols in 78 papers 23 publications were not in article format, case reports totaled 6 articles and 5 articles were not written in the language proposed by the survey (Figure 1).

After applying the exclusion criteria, 13 studies remained the Medline/PubMed database, included in this review, aiming to analyze the use of hydrotherapy, electrotherapy and therapeutic exercise in treating fibromyalgia (Table 2). The search with fibromyalgia descriptors and physiotherapy was the one with the largest number of articles (11 publications).

The criteria of methodological of Jadad quality scale (1996), the jobs gained 3 points or more were included and considered potentially relevant. Of the 13 studies selected, all had adequate randomization and showed a good method of masking. Among the articles, five were described as double-blind, three reported no losses and larger deletions than $10 \%$ of the sample (Table 3 and Table 4).

\section{DISCUSSION}

This systematic review was conducted using as a tool the Jadad scale, allowing evaluate clinical studies, published in leading databases, addressing the use of physical therapy

Table 1. Statement of articles indexed in the databases searched.

\begin{tabular}{lccc}
\hline \multicolumn{1}{c}{ Descriptors } & LILACS & SCIELO & MEDLINE \\
\hline $\begin{array}{l}\text { Fibromyalgia and physiotherapy } \\
\text { Fibromyalgia and exercise and }\end{array}$ & 10 & 2 & 420 \\
kinesiotherapy & 1 & - & - \\
Fibromyalgia and electrotherapy & 2 & - & 46 \\
Fibromyalgia and hydrotherapy & 9 & 2 & 30 \\
Total articles & & & 522 \\
\hline
\end{tabular}

Table 2. Statement of indexed articles included in the search.

\begin{tabular}{lccc}
\multicolumn{1}{c}{ Descriptors } & LILACS & SCIELO & MEDLINE \\
\hline Fibromyalgia and physiotherapy & - & - & 11 \\
$\begin{array}{l}\text { Fibromyalgia and exercise and } \\
\text { kinesiotherapy }\end{array}$ & - & - & - \\
Fibromyalgia and electrotherapy & - & - & 1 \\
Fibromyalgia and hydrotherapy & - & - & 1 \\
Articles included in the study & 0 & 0 & 13 \\
\hline
\end{tabular}

\begin{tabular}{|l|c|}
\hline \multicolumn{1}{|c|}{ Exclusion criteria } & No articles \\
\hline - Review articles & 118 \\
\hline - Experimental animal studies & - \\
\hline - Case reports or editorials & 6 \\
\hline - Articles only relate to quality of life & 3 \\
\hline - Documents that are not in article format & 23 \\
\hline - Articles that do not explored the theme of the study or not detailed protocols & 78 \\
\hline - Items not available & 183 \\
\hline - Articles not written in English, Portuguese or Spanish & 5 \\
\hline - Items not selected by the Jadad scale (1996) & 93 \\
\hline
\end{tabular}

Figure 1. Statement of indexed items excluded in the search. 
Table 3. Methodological analysis of articles according to Jadad Quality Scale

\begin{tabular}{|c|c|c|c|c|c|c|}
\hline \multirow{2}{*}{ Author/Year } & \multicolumn{5}{|c|}{ Criteria } & \multirow{2}{*}{ TOTAL } \\
\hline & A & B & C & D & E & \\
\hline ATLAN et al., 2009 & absent & present & absent & present & present & 3 \\
\hline CASANUEVA-FERNANDEZ et al., 2012 & absent & present & present & present & absent & 3 \\
\hline DONMEZ et al., 2005 & absent & present & absent & present & present & 3 \\
\hline EVCIK et al., 2008 & absent & present & absent & present & present & 3 \\
\hline EVICIK et al., 2002 & absent & present & absent & present & present & 3 \\
\hline FREGNI et al., 2006 & absent & present & present & present & present & 4 \\
\hline HARGROVE et al., 2012 & absent & present & present & present & absent & 3 \\
\hline MENDONCA et al., 2011. & absent & present & present & present & present & 4 \\
\hline SANUDO et al., 2011 & absent & present & absent & present & present & 3 \\
\hline TAYLOR et al., 2013 & absent & present & present & present & absent & 3 \\
\hline TOMAS-CARUS et al., 2007 & absent & present & absent & present & present & 3 \\
\hline TOMAS-CARUS et al., 2009 & absent & present & absent & present & present & 3 \\
\hline VITORINO et al., 2006 & absent & present & absent & present & present & 3 \\
\hline
\end{tabular}

A: The study was defined as random, B: The method of randomization was adequate C: The study was described as double-blind, D: The masking method was adequate and E: There was reports of losses and exclusions.

Table 4. Summary of the review.

\begin{tabular}{|c|c|c|c|c|c|}
\hline Author/Year & $\begin{array}{c}\text { Type of study } \\
\text { and sample size (n) }\end{array}$ & Study design & $\begin{array}{l}\text { Duration of } \\
\text { intervention } \\
\text { (months) }\end{array}$ & Study losses & Results \\
\hline EVCIK et al., 2002. & $\begin{array}{l}\text { Randomized controlled } \\
\text { clinical trial } \\
n=42\end{array}$ & $\begin{array}{l}\text { To evaluate the effectiveness } \\
\text { of thermal therapy in the } \\
\text { treatment of patients with } \\
\text { fibromyalgia. }\end{array}$ & 3 weeks & $\begin{array}{c}\text { Not } \\
\text { occurred }\end{array}$ & $\begin{array}{l}\text { After completion of treatment with } \\
\text { balneotherapy improvement was } \\
\text { observed in the number of tender } \\
\text { points, pain and symptoms of } \\
\text { fibromyalgia. }\end{array}$ \\
\hline DÖNMEZ et al., 2005. & $\begin{array}{l}\text { Randomized controlled } \\
\text { clinical trial } \\
\mathrm{n}=30\end{array}$ & $\begin{array}{l}\text { To compare the effects of } \\
\text { spa therapy in relation to } \\
\text { medical treatment commonly } \\
\text { prescribed for patients with } \\
\text { fibromyalgia. }\end{array}$ & 2 weeks & yes & $\begin{array}{l}\text { Treatment with spa therapy showed } \\
\text { significant improvement in pain, } \\
\text { reduction in tender point count, sleep } \\
\text { disturbance, fatigue, and symptoms } \\
\text { evidenced in FIQ Beck inventory up to } 9 \\
\text { months after treatment. }\end{array}$ \\
\hline FREGNI et al., 2006. & $\begin{array}{l}\text { Randomized controlled } \\
\text { clinical trial } \\
\mathrm{n}=32\end{array}$ & $\begin{array}{l}\text { To investigate whether } \\
\text { treatment with electric } \\
\text { transcranial direct-current } \\
\text { stimulation results in } \\
\text { relieving pain in patients with } \\
\text { fibromyalgia. }\end{array}$ & 40 days & yes & $\begin{array}{l}\text { Conducted therapy in the primary motor } \\
\text { cortex achieve a significant improvement } \\
\text { in pain, anxiety and depression in this } \\
\text { population. }\end{array}$ \\
\hline VITORINO et al., 2006. & $\begin{array}{l}\text { Randomized controlled } \\
\text { clinical trial } \\
n=50\end{array}$ & $\begin{array}{l}\text { To compare hydrotherapy and } \\
\text { conventional therapy in the } \\
\text { treatment of fibromyalgia, } \\
\text { related quality of life, total } \\
\text { sleep time and total time nap. }\end{array}$ & 3 weeks & Yes & $\begin{array}{l}\text { Any hydrotherapy as conventional } \\
\text { therapy promotes improvements } \\
\text { in quality of life, total sleep time, } \\
\text { and decrease in total nap time, and } \\
\text { hydrotherapy had the greatest effect on } \\
\text { total sleep time, and decrease in total } \\
\text { doze time on the population studied. }\end{array}$ \\
\hline $\begin{array}{l}\text { TOMAS-CARUS et al., } \\
2007 .\end{array}$ & $\begin{array}{l}\text { Randomized controlled } \\
\text { clinical trial } \\
n=34\end{array}$ & $\begin{array}{l}\text { Evaluate the effects of a } \\
\text { period of water training and } \\
\text { the quality of life related to } \\
\text { health and physical fitness in } \\
\text { women with fibromyalgia. }\end{array}$ & 12 weeks & Not occured & $\begin{array}{l}\text { Significant positive effects of aquatic } \\
\text { training were found in physical function, } \\
\text { bodily pain, general health perceptions, } \\
\text { vitality, social function, emotional } \\
\text { problems and mental health, balance } \\
\text { and climb stairs. After the intervention } \\
\text { period, there was improvement in pain } \\
\text { in the body and emotional problems } \\
\text { were kept. }\end{array}$ \\
\hline
\end{tabular}


Table 4. Continued...

\begin{tabular}{|c|c|c|c|c|c|}
\hline Author/Year & $\begin{array}{c}\text { Type of study } \\
\text { and sample size (n) }\end{array}$ & Study design & $\begin{array}{l}\text { Duration of } \\
\text { intervention } \\
\text { (months) }\end{array}$ & Study losses & Results \\
\hline EVCIK et al., 2008. & $\begin{array}{l}\text { Randomized controlled } \\
\text { clinical trial } \\
n=63\end{array}$ & $\begin{array}{l}\text { To investigate the } \\
\text { effectiveness of aquatic } \\
\text { exercise in fibromyalgia } \\
\text { syndrome. }\end{array}$ & 5 weeks & Yes & $\begin{array}{l}\text { At the end of treatment was observed } \\
\text { improvements in the FIQ scores and } \\
\text { decrease in the number of tender points. } \\
\text { There were improvements in depression } \\
\text { and levels of pain after aquatic therapy. }\end{array}$ \\
\hline ALTAN et al., 2009. & $\begin{array}{l}\text { Randomized, } \\
\text { prospective, blinded } \\
\text { and controlled } \\
n=50\end{array}$ & $\begin{array}{l}\text { To investigate the effect of } \\
\text { Pilates against pain, functional } \\
\text { status and quality of life in } \\
\text { patients with fibromyalgia. }\end{array}$ & 12 weeks & Yes & $\begin{array}{l}\text { Both in the treatment group as Pilates } \\
\text { the exercise group were improvements } \\
\text { in FIQ parameters and pain. After } 12 \\
\text { weeks of treatment group was treated } \\
\text { with pilates who remained with effective } \\
\text { results. }\end{array}$ \\
\hline
\end{tabular}

After treatment with exercise found

To assess changes in muscle 2009.

clinical trial

$n=30$
TOMAS-CARUS et al., Randomized controlled strength during 32 weeks of supervised aquatic training, quality of life and postural balance.
32 weeks Yes improvements in the strength of flexor and extensor muscles of the knee (concentric), knee extensors (eccentric) and postural balance. The treatment also led to improvements in physical function (pain, mental health, vitality, emotional problems, physical and mental health).

The groups treated with Cathode-SO and of current and analgesic effects in the short term electric transcranial directcurrent stimulation in fibromyalgia

To assess the impact of program combining aerobic, Randomized controlled strength and flexibility verses SAÑUDO et al., 2011. clinical trial usual care in the perception of health, functional capacity, health and depression in patients with fibromyalgia.

To evaluate the effectiveness of a multidisciplinary

CASANUEVAFERNANDEZ et al., 2011.

Randomized, prospective, double treatment (massage, ischemic blinded and controlled $\mathrm{n}=34$

\section{pressure, aerobic exercise and} thermotherapy) in severely affected patients with fibromyalgia.

\section{0 months Not occured Anode-SO were followed improvement} of pain in fibromyalgia patients.
The results showed that the combined program of moderate exercise applied 24 weeks Yes twice a week improved the function and quality of life of patients with fibromyalgia.
At the end of treatment there was significant improvement in the experimental group compared to perceived health, social functioning, grip strength test and the six-minute walk.
To evaluate the efficacy, safety and tolerability of noninvasive cortical electrical stimulation in the treatment of fibromyalgia.

To investigate the effects of electrical stimulation therapy cranial electrical microcurrent (CES) on activity in brain regions of pain processing.

\section{HARGROVE et al.,} 2012. controlled. $\mathrm{n}=77$

\section{Randomized}

TAYLOR et al., 2013. prospective, double blinded and controlled $\mathrm{n}=57$ resources in addressing the symptoms of fibromyalgia, which is currently an important public health problem.

Regarding the use of electrotherapic resources for the relief of pain in patients with fibromyalgia, studies of the type randomized, controlled clinical trial ${ }^{(26-28)}$ used the direct current stimulation (TDCS) in the treatment of patients. Fregni et al. ${ }^{(26)}$ used a placebo group and two other groups, wherein one group received continuous current in the motor cortex and another group in the dorsolateral prefrontal cortex of the left side, and shows consisting of 32 female patients. They concluded that the therapy conducted in primary motor cortex obtained a significant improvement in painful symptoms $(p=0.05)$ and anxiety $(p<0.0001)$. In the study by Mendonca et $\mathrm{al}^{(27)}$ was carried out with 30 patients, the same modulation 
previous work was used and participants are assigned to 5 different groups (Cathode-M1 [electrode positioned at the primary motor cortex region], Cathode-SO [supraorbital area], Anode-M1, Anode-SO and placebo), receiving application via a mounting extracefálica for 10 months. Applications with the Cathode-SO and Anode-SO show significant analgesic effects, $p=0.010$ and $p=0.015$, respectively.

Following the same approach, Taylor et al.(28) coordinate a prospective, double-blind, placebo-controlled trial with 58 subjects with fibromyalgia, which aimed to investigate the effects of transcranial electric stimulation (microcurrent) on the activity in brain regions processing pain, over 8 weeks, with duration of 60 minutes per day. Participants in the intervention group received loads of $0.5 \mathrm{~Hz}$ and $100 \mu \mathrm{A}$ of a stimulator device (Alpha-Stim CES), while the placebo group wore a yesulador device, in which no electrical signal was not sent. The subjects receiving the load of the stimulator had a considerable improvement in the average for pain $(p=0.023)$ than those in the placebo group. Hargrove et al, ${ }^{(29)}$ for 11 weeks, assessed the efficacy, safety and tolerability of noninvasive cortical electrical stimulation $(10 \mathrm{kHz}$, in the form of one or more low-frequency components, usually $40 \mathrm{~Hz}$ ) in the treatment of fibromyalgia, and achieved improvement in the number of tender points $(p<0.001)$ in pain threshold $(p<0.001)$, fatigue $(p=0.02)$ and refreshing sleep $(p=0.02)$. We observed in these studies that electrotherapy treatment showed its effectiveness in the process of reduction of fibromyalgia symptoms with the use of electrical stimulation, low intensity, especially in the primary motor cortex, providing benefits with respect to pain control.

Regarding the hydrotherapy in relation to clinical determinants that affect the fibromyalgia patients, studies have been conducted in order to alleviate the symptoms of this disease. Dönmez et al. ${ }^{\left({ }^{30)}\right.}$ compared the effectiveness of a SPA therapy for treating the symptoms of fibromyalgia in relation to medical treatment commonly used. The treatment consisted of soaking in a thermal heated at $36^{\circ} \mathrm{C}$ for 20 minutes for 6 days a week, with pressurized thermal water bath heated to $37^{\circ} \mathrm{C}$ for 15 minutes or massage for 15 minutes. After completion of the treatment in a significant improvement SPA therapy was observed in the general pain $(p<0.001)$, the decrease in the number of tender points $(p=0.001)$ in sleep disturbance $(p=0.002)$, the fatigue $(p=0.001)$ and depression $(p=0.002)$ for up to 9 months after treatment. The same result was observed in the study Evicik et al. ${ }^{(31)}$ in a randomized controlled trial, using the same procedure for the treatment, heated bath to $36^{\circ} \mathrm{C}$, once a day, five times a week for 20 minutes, totaling 15 sessions. Em relação ao grupo controle, verificaram uma diminuição no número de tender points $(p<0,001)$ e da dor $(p=0,05)$. Later, Evicik et al. (32) performed a new intervention, with 20 minutes of exercises out of the pool, followed by 35 minutes of exercise in the pool heated to $33^{\circ} \mathrm{C}$, while the control group received only exercises performed at home. After 15 sessions, divided into 3 times a week for 5 weeks, improvement was observed in Impact Questionnaire scores of functional capacity (for the intervention group, $p=0.002$ and for the control group, $p=0.001$ ) compared to the reduction the number of tender points (for the intervention group, $p=0.009$ and for the control group, $p=0.016$ ) in reducing pain symptoms (for the intervention group, $p<0.001$ and for the control group, $p=0.003$ ) and symptoms of depression (for the intervention group, $p=0.005$ and for the control group, $p<0.001)$. However, the beneficial effect remained only in the group that underwent hydrotherapy.

Regarding to conventional therapy, Vitorino et al. ${ }^{(33)}$ conducted a randomized controlled trial to evaluate the quality of life, total sleep time and total nap time using a group, hydrotherapy, the exercises, stretching and relaxation and in the other group, infrared therapy, exercises, stretching and relaxation. At the end of the study, improved quality of life $(P<0.05)$ in both groups and all 24 patients in the treated group increased hydrotherapy 1 hour total sleep time $(p<0.01)$ and decreased total time nap $(p<0.05)$ compared to the group treated with infrared therapy. Another study in the aquatic environment was conducted by Tomas-Carus et al. ${ }^{(34)}$ which used a water training technique and physical fitness, to evaluate the health and quality of life of the participants. After the water training, physical function and bodily pain improved significantly, with $p=0.029$ and $p=0.030$, respectively. Considering the quality of life indicators, with regard to general health perception, vitality, social function, emotional problems and mental health, all were significant. When analizazed the balance, the ability to climb stairs with and without resistance, significant results were obtained after a period of 3 months. However, only the reduction of body pain and the emotional problems were maintained. Later, Tomas-Carus et al. (35) assessed the impact of muscle strength after a water training supervised in the balance, and found improved quality of life in all domains of the SF-36, with the exception of social function. Although the applied protocols are different, the effects such as improvement of pain, reduction in the number of tender points and depression were equivalent and important, in most studies that have been conducted using the hydrotherapy. Thus, hydrotherapy is of fundamental importance for functional recovery and especially for the relief of pain in fibromyalgia patients.

The exercise of various forms, has been an important support in the recovery of patients with fibromyalgia. Altan et al. ${ }^{(36)}$ in a randomized, prospective, 50 subjects evaluated the effect of Pilates technique in reducing pain symptoms, functional status and quality of life of patients with fibromyalgia. In the Pilates group were observed significant results regarding the improvement of pain, number of tender points, the scores of the impact of functional capacity, the Nottinghan scores of the health profile and algometrics scores, while the control group (intervention home exercises) improvements were identified only in the number of tender points and algométricos scores. 
However, the assessment carried out 12 weeks after the study, only remained the benefits effects in the group that performed the pilates. Sañudo et al. ${ }^{(37)}$ evaluated the effectiveness of a program, lasting 24 weeks, combining cardio, strength and flexibility in patients with fibromyalgia. The results showed that the program was carried out with a moderate intensity, applied twice weekly, obtained significant improvements in SF-36 scores in the context of mental health, vitality, general health, physical function and the impact of the condition functional patients.

The effectiveness of a multidisciplinary treatment applied in fibromyalgia patients was evaluated by Casanueva-Fernandez et al. ${ }^{(38)}$ in a randomized controlled prospective, double-blind. The protocol consisted of massage, pressure on tender points, cardio and thermotherapy through the infrared. Both patients in the control group and the intervention group received one hour, four educational sessions that addressed relaxation techniques, cognitive-behavioral therapy, diet and explanations about the benefits of exercise in patients with fibromyalgia. One month after the end of treatment, there was a significant improvement in the intervention group compared to the perception of health, social functioning, grip strength test and the six-minute walk.

Some methodological limitations found in this review. The non details of the protocols used in intervention, the lack of control group identification, side effects, and especially no description of the number of losses throughout the study, were the most frequent.

\section{CONCLUSION}

This systematic review found that there were a small number of studies in various databases with scientific relevance, published in the last 10 years, highlighting the techniques have worked best in the treatment of fibromyalgia sufferers.

It is suggestive that future, larger and more systematic studies are organized to ensure a more adequate and well-defined protocol and a relevant epidemiological design and an appropriate and organized study model, so that there is a more concrete and relevant approach, featuring a scientific rigor, the opportunity to safer results.

\section{AUTHOR'S CONTRIBUTION}

AJSN: data collection, analysis and interpretation of data and the wording of article; MFAB and AGCC: conception, study design, data collection, analysis and interpretation of data and the wording of article; MGRA and NMGL: analysis and interpretation of data and the wording of article.

\section{FINANCIAL COMPETING INTERESTS}

The authors declare no conflict of interest.

\section{AUHTOR DETAILS}

${ }^{1}$ Fisioterapia em Saude Coletiva Laboratory (LabFISC) of the Nucleo de Estudos e Pesquisas Epidemiológicas em Fisioterapia e Saúde (NEPEFIS), Joao Pessoa (PB), Brazil; ${ }^{3}$ Physical Therapy Department of Universidade
Federal de Pernambuco (UFPE); researcher from the Cinesioterapia e Recursos Terapêuticos Manuais Laboratory from Universidade Federal de Pernambuco, Recife (PE), Brazil; ${ }^{4}$ Physical Therapy Department of Universidade Federal da Paraíba (UFPB); researcher from the Ergonomia e Saúde (LABES) of the Nucleo de Estudos e Pesquisas Epidemiológicas em Fisioterapia e Saúde (NEPEFIS), Recife (PE), Brazil.

\section{REFERENCES}

1. Martinez JE, Panossian C, Gaviolli F. Estudo comparativo das características clínicas e abordagem de pacientes com fibromialgia atendidas em serviço público de reumatologia e em consultórios particulares. Rev Bras Reumat. 2006;46(1):32-6

2. Queiroz LP. Worldwide epidemiology of fibromyalgia. Curr Pain Headache Rep. 2013;17(8):356.

3. Senna ER, Barros AL, Silva EO, Costa IF, Pereira LV, Ciconelli RM, et al. Prevalence of Rheumatic Diseases in Brazil: A Study Using the COPCORD Approach J Rheumatol. 2004;31(3):594-7.

4. Santos AM, Burti JS, Lopes JB, Scazufca M, Marques AP, Pereira RM. Prevalence of fibromyalgia and chronic widespread pain in communitydwelling elderly subjects living in São Paulo, Brazil. Maturitas. 2010;67(3):251-5.

5. Wolfe F, Smythe HA, Yunus MB, Bennett RM, Bombardier C, Goldenberg $\mathrm{DL}$, et al. The American College of Rheumatology 1990 criteria for the classification of fibromyalgia. Arthritis \& Rheumatism. 1990;33(2):160-72.

6. Wolfe F, Clauw DJ, Fitzcharles M, Goldenberg DL, Katz RS, Mease P, et al. The American College of Rheumatology preliminary diagnostic criteria for fibromyalgia and measurement of symptom severity. Arthritis Care Res. 2010;62(5):600-10.

7. Wolfe F, Clauw DJ, Fitzcharles M, Goldenberg DL, Hauser H, Katz RS, et al. Fibromyalgia criteria and severity scales for clinical and epidemiological studies: a modification of the ACR preliminary diagnostic criteria for fibromyalgia. J Rheumatol. 2011;38(6);1113-22.

8. Ozgocmen S, Ozyurt H, Sogut S, Akyol O. Current concepts in the pathophysiology of fibromyalgia: the potential role of oxidative stress and nitric oxide. Rheumt Inter. 2006;26(7):585-97.

9. Arnold IM, Fan J, Russell IJ, Yunus MB, Khan MA, Kushner I, et al. The Fibromyalgia Family Study. A Genome-Wide Linkage Scan Study. Arthritis \& Rheumatism. 2013;65(4):1122-8.

10. Bellato E, Marini E, Castoldi F, Barbasetti N, Mattei I, Bonasia DE, et al. Fibromyalgia Syndrome: Etiology, Pathogenesis, Diagnosis, and Treatment. Pain Research and Treatment. 2013;2013:960270.

11. Thompson ME, Barkhuizen A. Fibromyalgia, Hepatitis $C$ Infection, and the Cytokine Connection. Current Pain and Headache Reports. 2003;7(5):342-7.

12. Berber JSS, Kuper E, Berber SC. Prevalence of depression and its relationship with quality of life in patients with fibromyalgia syndrome. Rev Bras Reumatol. 2005;45(2):47-54.

13. Mease P. Fibromyalgia Syndrome: Review of Clinical Presentation, Pathogenesis, Outcome Measures, and Treatment J Rheumatol. 2005;32(10 Sup):2063.

14. Velly AM, Look JO, Schiffman E, Lenton PA, Kang W, Messner RP, et al. The Effect of Fibromyalgia and Widespread Pain on the Clinically Significant Temporomandibular Muscle and Joint Pain Disorders - A Prospective 18-Month Cohort Study. J Pain, 2010;11(11):1155-64.

15. Barros MFA, Silva IMM, Nascimento JA, Oliveira EA, Cardia MCG, Lucena NMG, et al. A percepção da qualidade de vida de pacientes fibromiálgicas submetidas à intervenção fisioterapêutica. R Bras Ci Saúde. 2012;16(Sup 2):3-10.

16. Meyer BB, Lemley KJ. Utilizing exercise to affect the symptomology of fibromyalgia: a pilot study. Med Scien Sport Exer. 2000;32(10):1691-7.

17. Clark SR, Jones KD, Burckhardt CS, Bennet R. Exercises for patients with fibromyalgia: risks versus benefits. Curr Rheum Repor. 2001;3(2):135-40.

18. Brecher LS, Cymet TC. Apratical approach to fibromyalgia. J Am Osteopath Assoc. 2001;101(4 Sup 2):S12-7. 
19. Reilly KA, Bird HA. Prophylactic hydrotherapy. Rheumatology. 2001;40(1):4-6.

20. Dias KSD. Melhora da qualidade da vida em pacientes fibromiálgicos tratados com hidroterapia. Rev Fisioter Brasil. 2003;4(5): 320-5.

21. Sluka KA, Walsh D. Transcutaneous electrical nerve stimulation: basic science mechanisms and clinical effectiveness. J Pain. 2003;4(3):109-21.

22. Löfgren $M$, Norrbrink C. Pain relief in women with fibromyalgia: a crossover study of superficial warth stimulation and transcutaneous electrical nerve stimulation. J Rehabil Med. 2009;41(7): 557-62.

23. Mutlu B, Paker N, Bugdayci D, Tekdos D, Kesiktas N. Efficacy of supervised exercise combined with transcutaneous electrical nerve stimulation in women with fibromyalgia: a prospective controlled study. Rheumatol Int. 2013;33(3):649-55.

24. Hecker CD, Melo C, Tomazoni SS, Martins ABL, Leal Júnior ECP. Análise dos efeitos da cinesioterapia e da hidrocinesioterapia sobre a qualidade de vida de pacientes com fibromialgia - um ensaio clínico randomizado. Fisioter Mov. 2011;24(1): 57-64.

25. Jadad AR, Moore RA, Carroll D, Jenkinson C, Reynolds DJM, Gavaghan DJ, et al. Assessing the Quality of Reports of Randomized Clinical Trials: Is Blinding Necessary? Control Clin Trials. 1996;17(1):1-12.

26. Fregni F, Gimenes R, Valle AC, Ferreira MJ, Rocha RR, Natalle I, et al. A randomized, sham-controlled, proof of principle study of transcranial direct current stimulation for the treatment of pain in fibromyalgia. Arthritis Rheum. 2006;54(12):3988-98.

27. Mendonça ME, Santana MB, Baptista AF, Datta A, Bikson M, Fregni $F$, et al. Transcranial DC stimulation in fibromyalgia: optimized cortical target supported by high-resolution computational models. J Pain. 2011;12(5):610-7.

28. Taylor AG, Anderson JG, Riedel SL, Lewis JE, Bourguignon C. A randomized, controlled, double-blind pilot study of the effects of cranial electrical stimulation on activity in brain pain processing regions in individuals with fibromyalgia. Explore (NY). 2013;9(1):32-40.
29. Hargrove JB, Bennett RM, Yesons DG, Smith SJ, Nagpal S, Deering DE. A Randomized Placebo-Controlled Study of Noninvasive Cortical Electrostimulation in the Treatment of Fibromyalgia Patients. Pain Med. 2012;13(1):115-24.

30. Dönmez A, Karagülle MZ, Tercan N, Dinler M, Işsever H, Karagülle M, et al. SPA therapy in fibromyalgia: a randomized controlled clinic study. Rheumatol Int. 2005;26(2):168-72.

31. Evcik D, Kizilay B, Gökçen E. The effects of balneotherapy on fibromyalgia patients. Rheumatol Int. 2002;22(2):56-9.

32. Evcik D, Yigit I, Pusak H, Kavuncu V. Effectiveness of aquatic therapy in the treatment of fibromyalgia syndrome: a randomized controlled open study. Rheumatol Int. 2008;(9):885-90.

33. Vitorino DFM, Carvalho IBC, Prado GF. Hydrotherapy and conventional physiotherapy improve total sleep time and quality of life of fibromyalgia patients: Randomized clinical trial. Sleep Medicine. 2006;7(3): 293-6.

34. Tomas-Carus P, Häkkinen A, Gusi N, Leal A, Häkkinen K, Ortega-Alonso A. Aquatic training and detraining on fitness and quality of life in fibromyalgia. Med Sci Sports Exerc. 2007;39(7):1044-50.

35. Tomas-Carus $P$, Gusi N, Häkkinen A, Häkkinen K, Raimundo A, OrtegaAlonso $\mathrm{A}$. Improvements of muscle strength predicted benefits in HRQOL and postural balance in women with fibromyalgia: an 8-month randomized controlled trial. Rheumatology (Oxford), 2009;48(9):1147-51.

36. Altan I, Korkmaz N, Bingol U, Gunay B. Effect of pilates training on people with fibromyalgia syndrome: a pilot study. Arch Phys Med Rehabil. 2009;90(12):1983-8.

37. Sañudo B, Galiano D, Carrasco I, Hoyo M, Mcveigh JG. Effects of a prolonged exercise program on key health outcomes in women with fibromyalgia: a randomized controlled trial. J Rehabil Med. 2011;43(6):521-6.

38. Casanueva-Fernández B, Ilorca J, Rubió JB, Rodero-Fernández B, GonzálezGay MA. Efficacy of a multidisciplinary treatment program in patients with severe fibromyalgia. Rheumatol Int. 2012;32(8):2497-502. 